\title{
Application of modular system for innovation buildings architectural design
}

\author{
Gholamali Kazemi Lary \\ Киевский национальный университет строительства и архитектуры \\ Воздухофлотский проспект 31, Киев, Украина, 03680 \\ alikazemilari@gmail.com, orcid.org/0000-0002-4094-073X
}

Получено 12.04.2019, принято после просмотра 26.05.2019

https://doi.org/10.31493/uwt1921.0102

\begin{abstract}
This article deals with the modular regulation techniques in the design of innovative enterprises in order to improve operational efficiency, as well as creating a more rational method of expansion and transformation. Consequently, the advantages of modular architecture in reducing the cost, labor and costs of building materials are compared with traditional methods. In addition, the contribution of further expansion of buildings by modular architecture is described. Based on scientific research, two classes of a modular system are defined for regulating the architectural structure of existing and new objects of an innovative enterprise: combined and specialized. Such systems are realized in the form of a grid, cellular structure and prefabricated units, which allow combining homogeneous and heterogeneous functional zones. At the same time, more acceptable module dimensions are determined for the main types of spaces in innovative enterprises: office, laboratory and production. The use of one or another type of modular solution, which adapts to the requirements of the terrain and the functional process of innovative buildings for various purposes, is recommended.
\end{abstract}

Modular unit techniques for the construction of temporary, permanent and mobile buildings of innovative enterprises are also presented in this article. Prefabricated modules, which include flat materials and spatial blocks, are considered. Metal, wood, plastic and reinforced concrete wrapped and blocks for creating modular systems are the subjects of study in this article. Also, some companies that have developed typical modular buildings from similar building materials are named. The methods of connecting and assembling elements from the modules both at the plant and at the construction site are analyzed. It also explains the

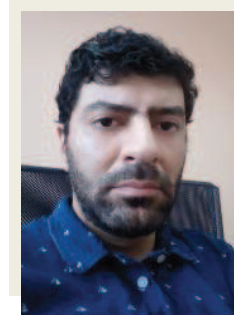

Лари Каземи Аспирант кафедры Архитектурного проектирования гражданских зданий и сооружений

relationship between the dimensions of modular structures and vehicles. Examples from world experience are given for each of these types.

Keywords: innovative enterprise, Science Park, modular system, universality, flexibility, functional area, functional cell.

\section{INTRODUCTION}

Modular construction as an accelerated construction method is an alternative for temporary and mobile architecture. Buildings designed in this way consist of sections (modules) prepared at the factory and contain internal technical facilities (electrical wire, water and sewer pipes). After the assembling modules on site, additional architectural finishes can be applied and the completed product is almost indistinguishable from the construction created by traditional methods.

However, modular architecture includes a broader concept than the use of prefabricated units to create a building. Modules can consist of separate prefabricated elements (columns, trusses, panels), combined according to the principle of determined repeating steps and spans. Thus, modular architecture is the best solution for some long-term, temporary or 
permanent facilities, such as construction camps, laboratories, schools and classrooms, civil and military housing, industrial facilities, churches, medical mobile buildings, sales offices and retail shopping centers, fast food restaurants and ticket offices.

\section{THE ROLE OF MODULAR DESIGN TO IMPROVE INNOVATIVE ENTERPRISES}

Based on the "theory of innovative enterprises" the characteristic features of an innovative enterprise (IE) are the accumulation, collectivity and variability of the innovation process in the management of company [4, p. 67]. IEs are dynamic buildings that, in accordance with the frequency of changes in research and production methods, are able to change their characteristics. Some architectural ways such as transformation of form and structure, dynamic lighting, the use of universal threedimensional elements are useful to achieve this goal [6, p.53]. Scientific achievements and the experience of advanced technologies in various fields promote innovative developments of engineering, technology, labor organization and management [5, p.129].

Science Parks are vivid examples of IE. There are 3 types of processes in a science park, which simultaneously appear with the growth of the enterprise and innovative progress: research and experiment; production; rent of office spaces. The territorial expansion of facilities is necessary for the cyclical development of the innovation process. However, it is not the single duty of innovative enterprises. The architectural design of innovative buildings should be based on the universality and flexibility, in order to promote the transformation of spaces, fluctuations in the number of personnel and the volume of production. A modular system allows implementing these priorities. The advantages of this solution are minimizing the necessary operational areas with maximum efficiency, expanding effective areas, creating universal spaces; observing the rhythm of transport and engineering communications; opportunities for industrialization of construction work; application of unified de- sign solutions; ability of open planning solutions.

\section{Recommended Classes for Modular Structures}

There are two classes of modular structures in order to plan an IE: combined and specialized. The combined modular structure is a common structural module that is used to host all clusters of an IE. This technique is used when using the existing infrastructure and in the formation of IE due to the reconstruction of other buildings; in the case when territorial limitation does not allow to form separate organization of functional groups; in the case of the chaotic IE at the level of the block, city and region (Fig. 1).

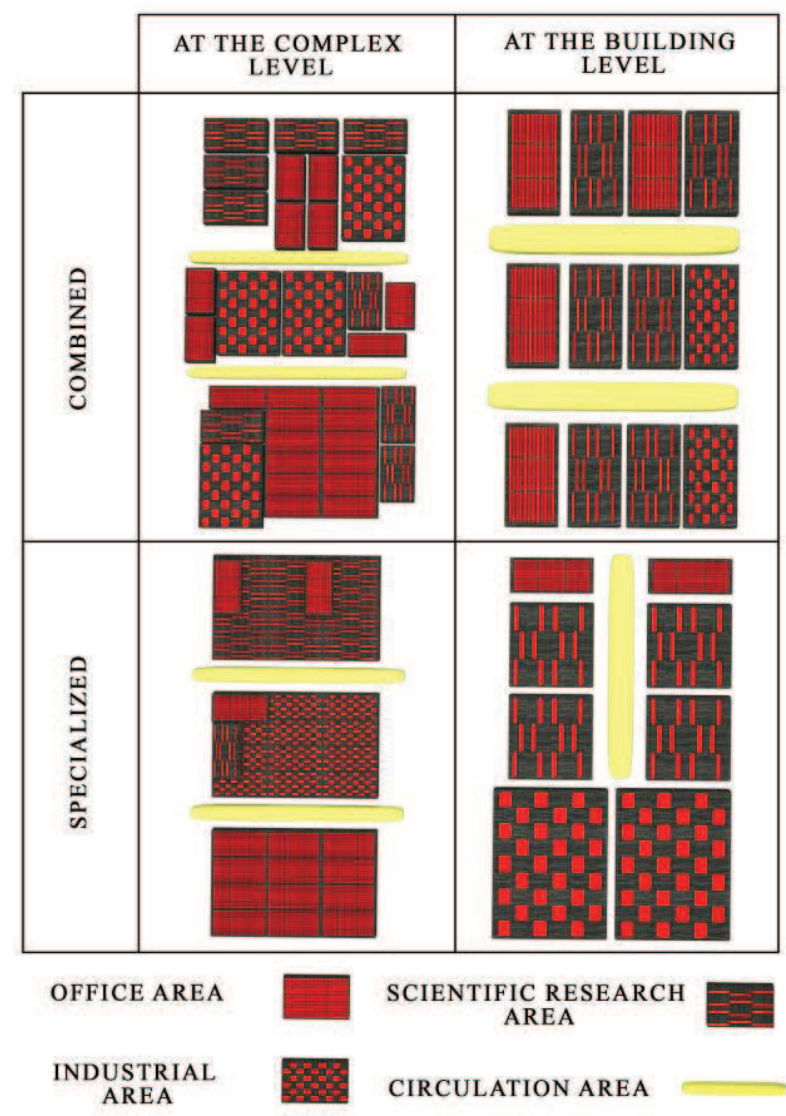

Fig.1. Modular structure's classes

Of course, this technique complicates future expansion and placement of heterogeneous functional areas in one building. In this case, the modular system can be partially or fully 
specialized. In the first case, heterogeneous, but functionally connected with each other spaces are organized within the framework of one module. Using this method, office premises are integrated in a laboratory modular system [14, p.29-46] (Fig. 2).

A full modular system allows organizing various functional groups. This method is used for large IEs that are formed in non-constructed areas.
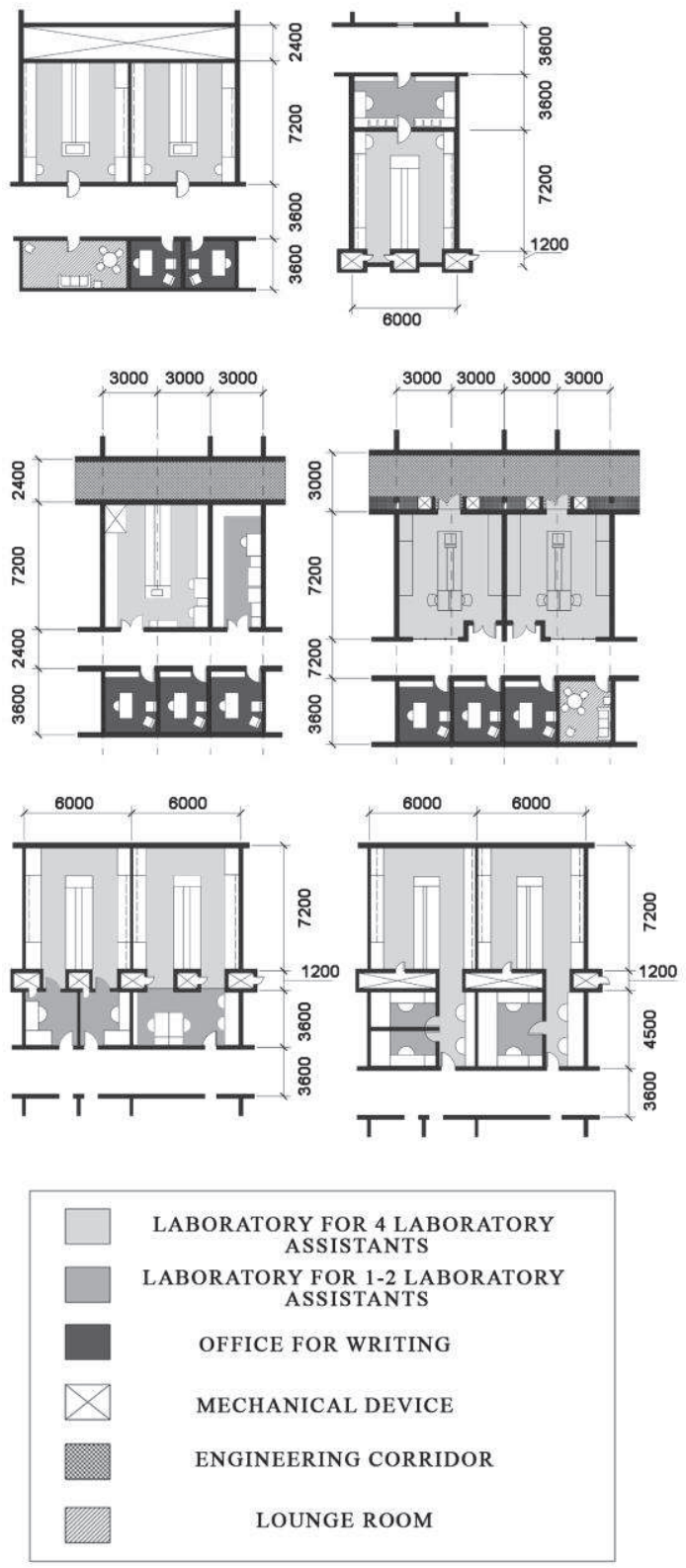

Fig. 2. Samples of a partially specialized modular structure on the example of laboratory facilities (according to [1] in the author's interpretation)
In this method, all vertical elements are integrated into the perimeter of the lab floors. Horizontal ducts run in interstitial floors [14, p.22].

The modules in innovative enterprises are the grid of functional zones in the master plan, cells with specific dimensions, prefabricated units and steps of the supporting structures. These modules can be either flat or spatial (3 dimensional). Modules should include the ratio of service and work areas. According the ergonomics a work post for each person should be at least $1.8 \times 1.8 \mathrm{~m}$ in plan, which can become a unit for the workplace, work cell, working field, building and urban planning module $[9$, p. 80]. The other modules are taken as a multiple correspondence of a cell $1.8 \times 1.8$ m., which can have different configurations, such as $3.6 ; 10.8 ; 21.6 ; 54.0 ; 72.0 ; 108.0$; $360.0 ; 1,080.0$. If in specific cases a smaller unit is needed, the steps should have a multiple correspondence of $30 \mathrm{~cm}$ (i.e. $0.3 ; 0.6 ; 1.2$ ). Practically more acceptable grids of columns are $3.6 ; 6 ; 9$ or $12 \mathrm{~m}$. Spans in accordance with the requirement can be $6 ; 9 ; 12 ; 18 ; 24 ; 30$; $36 \mathrm{~m}$.

For office and laboratory premises, a modular size of the width of is accepted, a multiple correspondence of $3.6 \mathrm{~m}$. Another issue in organization of laboratory-office module is the problem of staff Interior flexibility. It typically takes about three years for a lab to be designed and built. During this time, an organization's research needs may change or the people doing the research may leave and be replaced by others. In either case, there is a good chance that the purpose of the lab will change. If the entire lab is fitted with new casework, the casework may have to be changed before anyone occupies the new laboratory. To minimize this problem, equipment zones should be created in the initial design. An equipment zone is an area that can be fitted with equipment, movable furniture, fixed casework, or a combination of any of these. The fixed casework is usually located on the outside wall, with islands defined as equipment zones. It may also be helpful to locate $90 \mathrm{~cm}$ to $180 \mathrm{~cm}$ equipment zones on the outside walls to accommodate cylinders near fume hoods and refrigerators at the perimeter [10, p.14].

It is possible to determine the division of common territory in master plan, for example, the distance from IE to transport stops and public facilities should be $360 \mathrm{~m}$, the length of 
residential streets $720 \mathrm{~m}$, highways and trunk engineering communications $1080 \mathrm{~m}$ [9, p. 82]. As a structure-forming basis for the planning arrangement of industrial facilities in a historical environment, a block-modular structure using a small-sized module $-3 \& 6 \mathrm{~m}$ can be used. The use of such a module allows taking into account the planning parameters of the existing development during adding new fragments and ensures the best master plan organization of the industrial facility [8, p.92]. To increase the efficiency of a modular system, it is necessary to create horizontally and vertically unified sectors. In this regard, units and block section systems are used. For example, laboratories with uniform spatial parameters are located in one unit, or bathrooms on all floors are in the same place. The height of the premises is determined by a multiple correspondence of $3 \mathrm{~m}$, which reaches more than $9.6 \mathrm{~m}$ in industrial premises, and more than 12 $\mathrm{m}$ in atrium-type buildings. However, a height above $6 \mathrm{~m}$ is not applicable for buildings with more than one floor.

The modular system depends on the type of planning solution. The key point in this regard is the location of workspaces around circulation areas (corridors, stairs, halls and courtyards). There are 3 main layouts of workspace location: linear, central or core and comb-like $[14$, p.47-50]. In the central design, the rooms are located around a hall or an atrium, and in the rest, around a corridor. The modular structure determined is based on these configurations. In some cases, the central layout is a universal place in which spaces are umbrellalike organized. It means that all the functional areas, which can have their own ceilings, are located under a common cover. An example of this type is the Electronic Products Factory and the Renault Distribution Center in Swindon, England (architect N. Foster). In such buildings, spaces are divided by partitions and furniture. Large-sized unit and pavilion modules are used for organizing spaces of a research and production. For example, the Antarctic Research Station Halley VI (Hugh Broughton and AECOM) and the Schlumberger Research Center in Cambridge (Fig. 3).
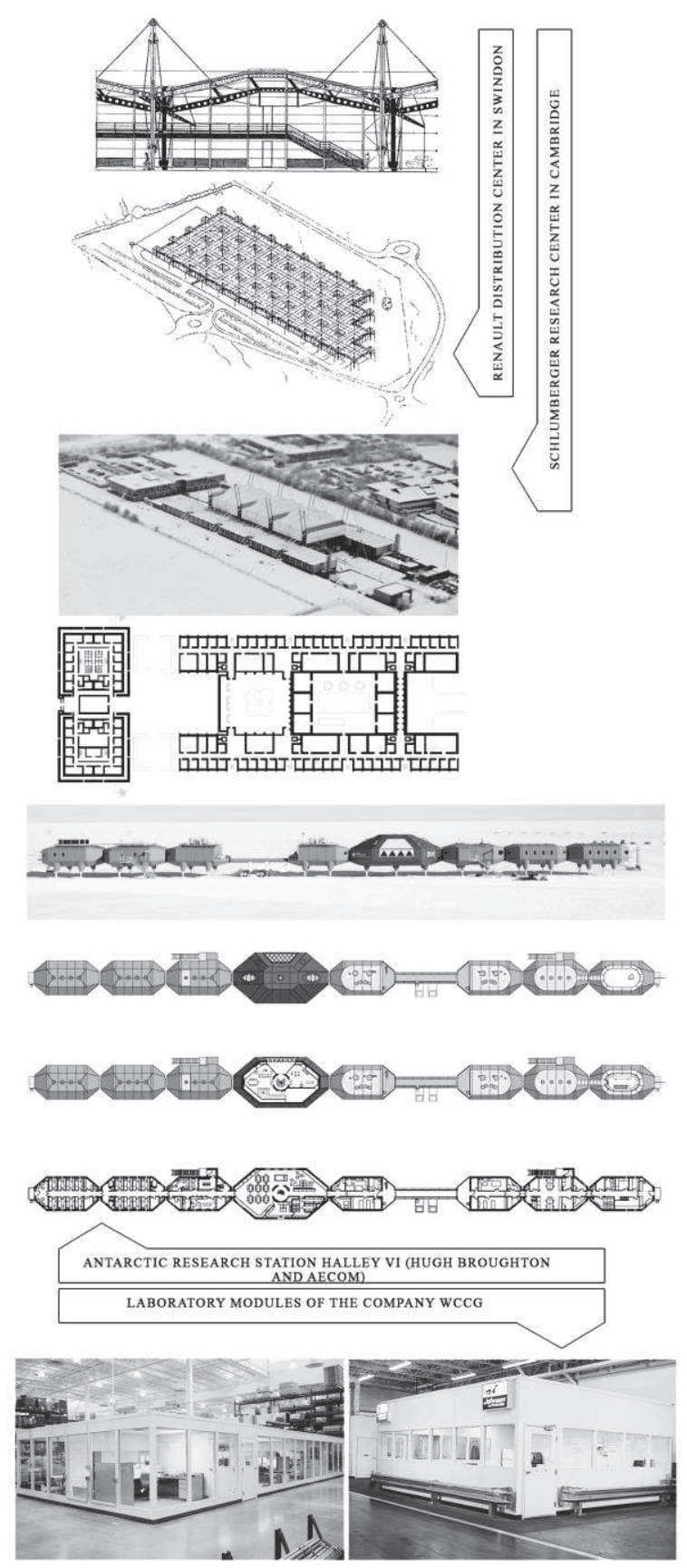

Fig. 3. The modular structural system for scientific and industrial purposes [sources of figures and photos: slideshare.net, tensinet.com, flickr.com, hbarchitects.co.uk, portafab.com]

Modular units are usually assembled in large production halls with a conveyor process. Modules are built in the factory within one to three months, and on-site construction can take only 10 days after relocation of building's parts. Even though to install the units a crane sometimes is necessary, but often they 
simply slide onto the foundation using forklifts. The assembly of modules can usually take several hours or several days, and the final product is indistinguishable from typical buildings built on by traditional methods.

Another way to build a modular system is to use volumetric-unit structures. These units can be separate or combined. Unit modular elements can be used on a large scale to create office-administrative spaces. The conveyor production of modular units can reduce the total cost by 1.8-2 times, the number of assembly elements by five times, and construction duration by three times [1, p.334]. An example of this type of building is the AZM bureau in Holland (architect L. Bisscher), the Plastic office in London (architect H. Stanley Smith) and the office pavilions of the Nardini distillery in Bassano Del Grappa, Vicenza, Italy (architect Massimiliano Fuksas). The press and information center in Tokyo (architect Kenzo Tange) is an example for the combination method (Fig. 4).

The volumetric-unit structures allow to increase or decrease the size of buildings by adding or removing modules without changing the basic structure. The same process can be used for transformation and functional change. Thus, the expansion and transformation of the building does not cause much delay in the exploitation of the enterprise.

The same method can be used to reduction of a company. Modules can be removed and sold as a separate, smaller building. In addition, it is possible to operate them for other purposes by adding or removing modules, or moving the building to another location.

Ultimately, there are some benefits to a modular architecture:

- Reduction of environmental impact;

- Less waste material in landfills;

- Labor and resource efficiency;

- Optimization of the construction process (in many cases, the completion of the construction process occurs 50 percent faster than conventional construction);

- Improving the safety and comfort of the construction process;

- The ability of synchronizing the stages of construction, which in traditional methods go consequently;

- Reducing the cost of building materials and work [17, p.4].
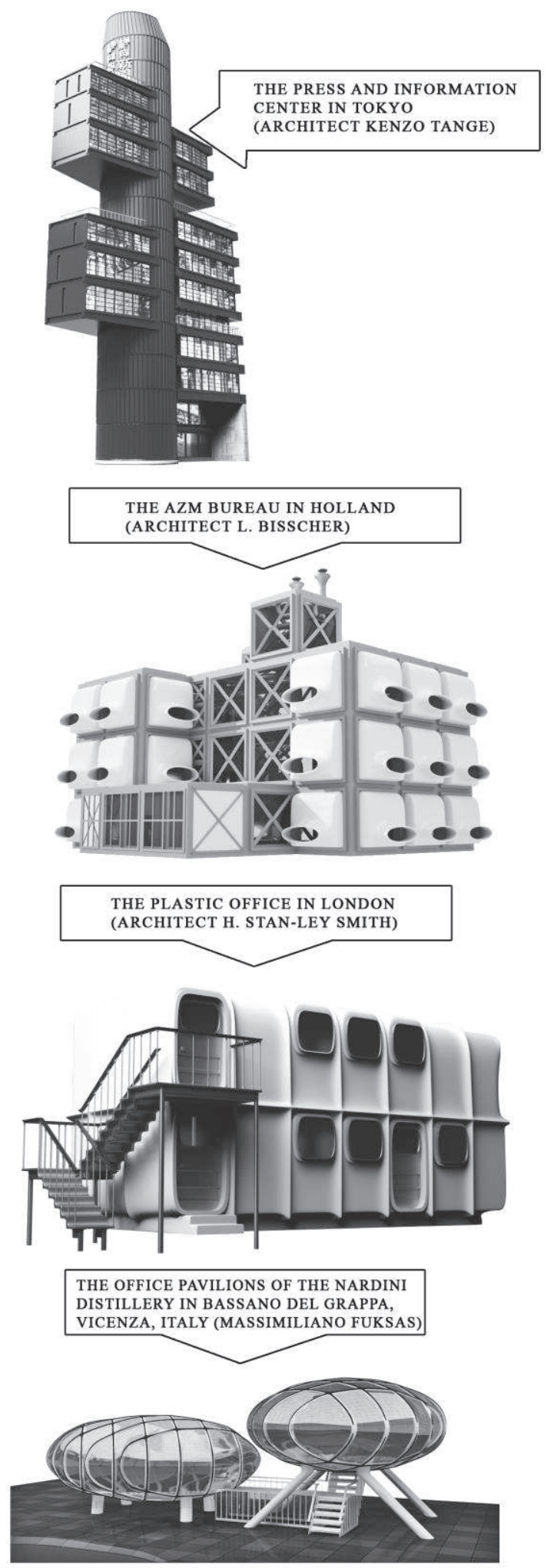

Fig. 4. The unit modules for office buildings 
However, the volumetric unit constructions have some disadvantages. Despite the flexibility of this system, the design of non-standard smooth forms is limited. Therefore, specific custom modules are required. In addition, the transportation of blocks depends on the dimensions of vehicles and road regulations. In addition, the number of levels of a modular building is limited. This limit depends on the country's standards. For example, in some Asian countries the construction of modular buildings up to 12 floors is accepted.

\section{The application of large modular units for the design of a production cluster}

Since in the frame-panel system not all construction work is completed at the factory (finishing, sanitary, installation remains for the construction site), along with the improvement of progressive frame structures, new systems with a high coefficient of factory readiness are being searched. In this regard, the use of large modular units can be an alternative to increase the speed of construction, as well as simplify the architectural transformation [2, p.334]. Innovative enterprises can include a production cluster or be formed as a part of an industrial district. Modular design is necessary to increase the efficiency of the production process, as well as separate areas with hazardous activities from office buildings. Production workshops, consisting of small unit modules can be combined and create large modular units. These large units govern the configuration of buildings and structures of the production cluster in accordance with existing conditions and requirements. The production process consists of three main stages: storage and supply of raw materials; treatment; the release and storage of the product. Therefore, workshops, buildings and structures, which are associated with each stage, can be considered as an independent unit (except in exceptional cases when technical solutions require combining the elements of two or all stages into one whole). Depending on the topographic features and shape of the site, as well as for the implementation of a more compact planning solution, it is possible to have different con-

figurations of production units: linear; parallel; P- and L-shaped; complex (Fig. 5).

A linear arrangement is preferable for production workshops, as this layout practically and psychologically is more rational. Parallel layout is a kind of linear type and is used when more than one production conveyor line exists.

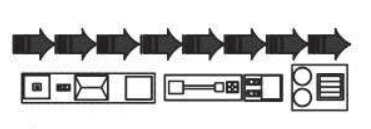

A
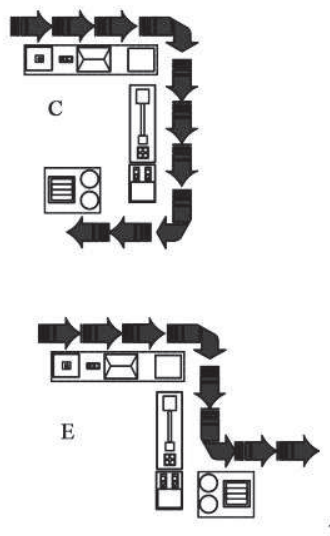

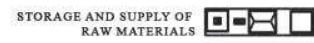

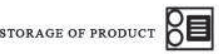

MANUFACTURING

A) LINEAR; B) PARALLEL; C) U-SHAPED; D) L-SHAPED; E) COMPLEX

Fig. 5. Layout techniques for the main constituent units of a production cluster

U-shaped layout is appropriate when the raw material and product storages are located near. Sometimes part of the unusable product is returned to the production line, but in this case additional storage facilities for return materials are required. L-shaped layout promotes the separation of entry and exit on the production site. It means that the raw materials are transporting in one direction, products are exported in another perpendicular direction.

Generally, dimensional requirements for modular units are determined by transportation restrictions. The more common dimensions are calculated as follows: the maximum width of the standard module is $3.8 \mathrm{~m}$, and the large $4.8 \mathrm{~m}$; the maximum length of the standard is $15.8 \mathrm{~m}$, and large: $18.3 \mathrm{~m}$; maximum module height $3.6 \mathrm{~m}$. The maximum height of the finished unit in the form of a building: from one to three floors for wooden blocks, from 5 to 12 for steel, from 12 to 20 for reinforced concrete $[18$, p.169, 175]. 


\section{Combination of modular elements}

In contemporary architecture, in order to increase efficiency, different materials are used to create modular units. For example, it is possible to make a metal frame, sheathe it with wooden panels with heat-insulating fiberglass layers, and at the end to mount it on a reinforced concrete foundation. Modular units can be created using various combination methods of elements:

- Single element method, where the same fundamental elements with different facade claddings are used;

- By the method of exchange of components, where the same fundamental elements are used, but by changing the parameters of the units after installation, various functions are assigned to each unit (the internal change);

- Cutting in size, where modules with the ability to cut into standard sizes for different purposes are used;

- applying a basic structure in the form of a frame and attach prefabricated elements to it;

- Sectional modularity, in which different elements are used, but are connected by one method to the basic structure and to each other [18, p.182-184].

The classification of modular elements is necessary to improve their application. The principles outlined in the preceding sections, concerned with the various devices which can be used to improve the efficiency of structures, can form the basis of a classification system for structural elements. The primary categorization is between form-active, semiformactive and non-form-active elements because this is the most important factor in determining the level of efficiency, which can be achieved. Elements are further classified according to the degree of 'improvement', which is present in their cross-sections and longitudinal profiles $[19$, p.45].

\section{Plastic modular units}

The first such modules were made in the UK in 1968. Plastic modular units can be used to provide temporary and mobile buildings for areas suffering from cataclysms, as well as for research and expeditionary work in extreme conditions. Other purposes of such a unit are exhibition pavilions, offices, checkpoints, camps, and temporary residential buildings, domestic and medical-operational premises. Plastic units made of compressed PVC sheets are most often produced in pentagonal and hexagonal forms, connected by bolts. Units are combined directly or using prefabricated corridors. In addition, vaulted modules from composite-laminate materials are practiced (such materials include multilayer cellulose, graphite, fiberglass, boron and silicon carbide plates). Such prefabricated units, in turn, are combined from separate prefabricated panels, connected with bolts and other similar reinforcing elements, or sealed with high temperature.

As a disadvantage, the working space in plastic containers is limited. However, they have also some advantages. For example, these units can be environmentally friendly and energy efficient. Existing landscape elements (earth, green cover) can be used as thermal facade insulation. This technology allows adaptation to topography and landscape environment, taking individual approaches and reducing the necessary amount of human resources for installation and dismantling due to the low weight of the constituent elements and the ease of installation process (usually 2-3 people are enough). Unlike other types of modular units (metallic and frame-panel units), technical elements (pipes, ventilation shafts, electrical wires) can be installed anywhere in the unit. On the other hand, plastic materials help to avoid overheating of the internal space of the units.

As examples of plastic modular blocks, two products of French manufacturers will be considered:

1. Wight's Isle, manufactured by Wight Plastics Limited Company, 1971. The basic module consists of six wall panels and 6 roof elements. There are sandwich elements made of two fiberglass layers of reinforced polyester, filled with foamed PVC. The assembly of various elements is carried out using galvanized steel bolts. 
2. Floating modules J. (1970). Architects Jacques Boeuf, Jean-Pierre Leverer, B. Gilet and M. Menager have designed these industrial, transformable, combinatorial and expandable units. Architects offered the existing technology of that time to create plastic bottoms and cases under the press. The diameters of the cases reached $3.5 \mathrm{~m}$. The shell elements are assembled using bolts and compression joints. These modules can be grouped to create settlements and coastal cities [20] (Fig. 6).

\section{Container-type units from metal truss and blocks}

Even though the containers were first created for industrial purposes (storage, laboratory, household), they were gradually used in the construction of office and residential buildings. There are two directions in the construction of modular container-type buildings:

1 - Reconstruction of metal storage containers by trimming and adding additional elements;

2 - The use of specially prepared elements, facade panels and technical blocks.

As a rule, modules distribute the load at bearing points on the foundation. Thus, a tiled floor with a perimeter system or columnar foundation is the best solution for a modular design. Typically, lightweight construction is not capable to hold a high-rise building, so such buildings cannot have more than three floors. Nevertheless, with additional reinforcing elements (the internal core and the diaphragm), it is possible to increase the number of levels to seven. In this case, it is worth using a strip foundation or piles in areas, where ground is sandy or the level of groundwater is high (Fig. 7).

Adding horizontal trusses, this system offers advantages of compact sizes, minimal welding, high rigidity, and the fewest possible column and connection points, since the corner posts transfer vertical loads to the foundation [11, p.36].

Such a solution, which is used in the American Kullman Frame System (KFS), eliminates the need for a solid foundation and reduces the
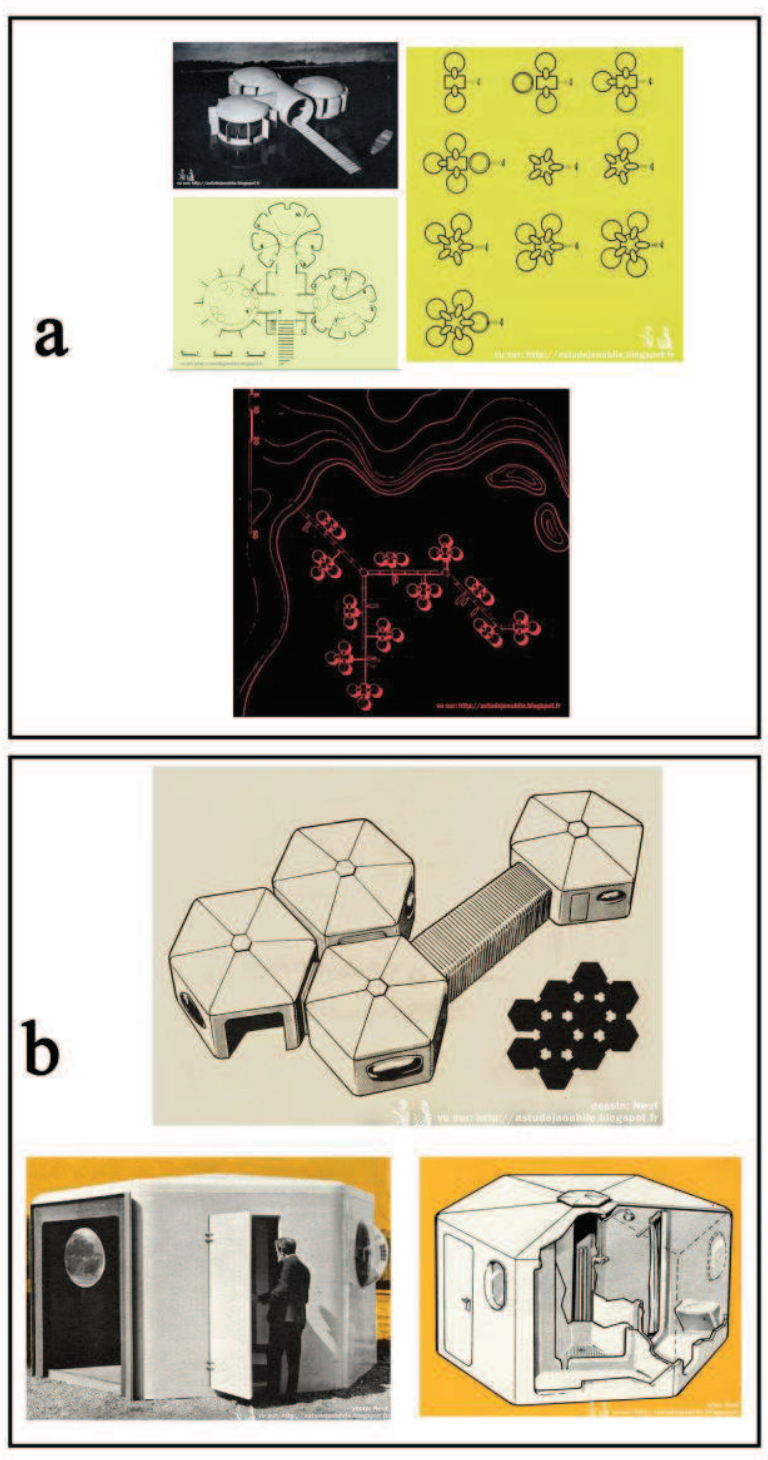

Fig. 6. Samples of plastic modular blocks [20]: $a$-Wight Isle (Isle Wight); $b$ - floating modules $-\mathrm{J}$

number of pillars [18, p.169] (Fig. 8). In addition, non-bearing units are used to place sanitary services, technical rooms or other modules that do not contain any load-bearing part of the building. These types of structures are typically constructed from lightweight steel structures.

These dimensions are proposed by KFS:

- Module Width: $13 \mathrm{ft}(396 \mathrm{~cm})$ Common Maximum, $16 \mathrm{ft}(487 \mathrm{~cm})$ Oversized Maximum Module 
- Length: $52 \mathrm{ft}(158 \mathrm{~cm})$ Common Maximum $60 \mathrm{ft}(183 \mathrm{~cm})$ Oversized Maximum

- Module Height: $12 \mathrm{ft}(366 \mathrm{~cm})$ Maximum

- Building Height: 12 Stories Maximum $[12$, p.35].

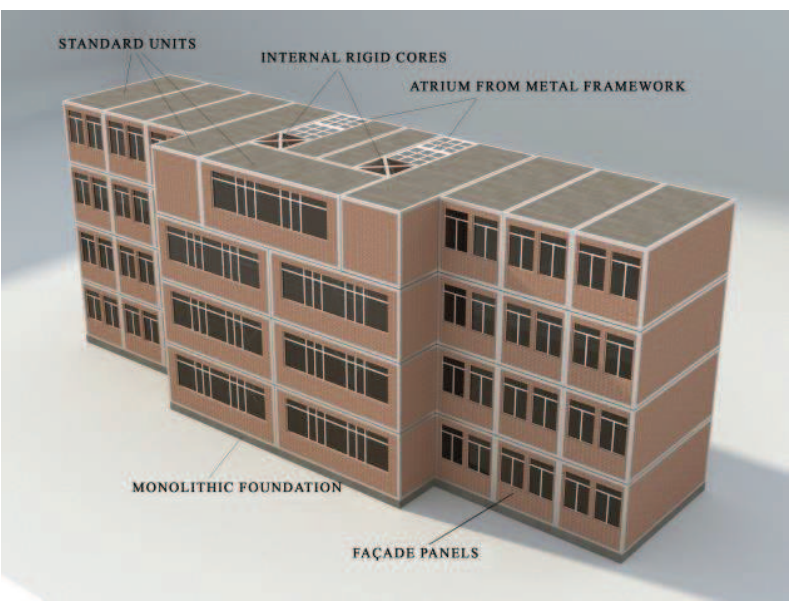

Fig. 7. Combining prefabricated units with an internal core and a monolithic foundation

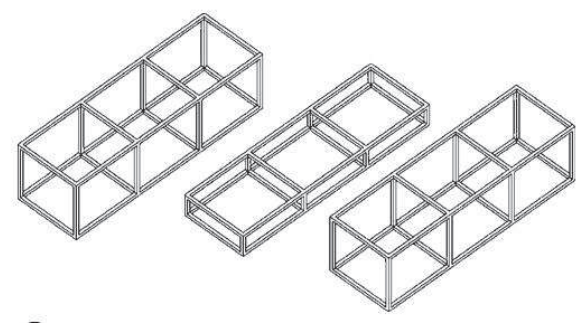

a

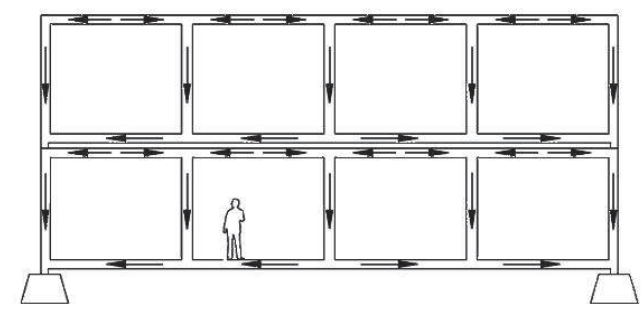

b

Fig. 8. Kullman Frame System (KFS) [11, p.36/18, p.169]: $a$ - modules which host intermediate submodules for the distribution of service rigs; $b-$ truss system of the "Virendel" beam box (a horizontal supporting structural element of the floor, working mainly on bending), which distributes the load on the external vertical posts of the module and the foundation

\section{Timber modules}

Ease of transportation, aesthetics, environmental friendliness, various construction methods and the ability to use modern and traditional forms are the advantages of wooden structures. However, the construction of wooden buildings over four floors due to increasing the costs, in order to strengthen the support points of the building is not economically justified. Thus, a combination of wood with other types of building materials is inevitable. Nevertheless, there are six, seven-story buildings of wooden modules.

There are some methods to simplify the assembling of timber frame modules:

A) Preparation of individual prefabricated elements: each element (wall and roof panels, floor slabs) is separately made as a twodimensional object. Modules are wrapped as two-dimensional planes. The floor is built at the factory, covered with a floor lining and positioned horizontally. Then panel walls constructed, sheathed, and tilted onto floor. The result is a three-dimensional assembly. The roof is built and craned on the walls. As a result, a finished unit is created;

B) The following steps can be applied for each of the above assemblies: install windows and doors. To execute wall finishes and roofing (plasterboard panels, plaster, siding, tile, slate, etc.). Transporting to the construction site $[18$, p.163].

The design of wooden modular buildings based on a method depends on social, economic and geographical conditions. Sometimes several methods can be combined. For example, the Moxy Hotel in Oslo (built in 2017), which consists of units located in the central part of the building and panels on both sides. The multilayer-glued wooden panels (CLT cross-laminated timber) are divided into two main groups - internal and external. The construction was performed by simultaneously expanding the arrays of modules in different directions (Fig.9). This structural system can be used for hostels, hospitals, offices, laboratories and multicompetent buildings [16, p.3-5]. 


\section{Reinforced concrete modules}

Unlike previous systems of large modules, this type of constructive solution is provided for a long-term period, because the installation and dismantling of units is more complicated. Reinforced concrete modules provide the ability to construct multistory buildings. However, due to the difficulty of transportation and dismantling, this type is not recommended for enterprises with a high pace of development. Such designs are used in the form of:

- Prefabricated panels and columns mounted with bolts and fasteners, welded rods and cables;

- Finished large units (individual or integrated segments);

- Monolithic modular construction [13, p.13-15].

An example based on reinforced concrete modules is Habitat 67 in Montreal (Fig.10, $a$ and $b$ ). Architect Moshe Safdi as the Canadian pavilion designed the building for the 1967 International Exhibition. It was an experimental solution for high-quality housing in dense urban environments [15, p.63-65].

Constructing low rise reinforced concrete buildings to reduce weight (especially in seismic regions), plastic blocks with cement can be combined. Another disadvantage of precast concrete modules is the low flexibility compared to monolithic reinforced concrete buildings. Since the dimensions of the precast elements are predetermined, the variety of exterior forms is limited. Despite this, precast concrete units or the so-called block rooms are built according to the principle of monolithic structures. Thus, with a large amount of production, their manufacture under specific requirements is economically viable.

To install prefabricated reinforced concrete structures, construction methods are based on: - Open systems (elements which are compatible with other components of the building)

- Closed systems (elements which are compatible only with each other).
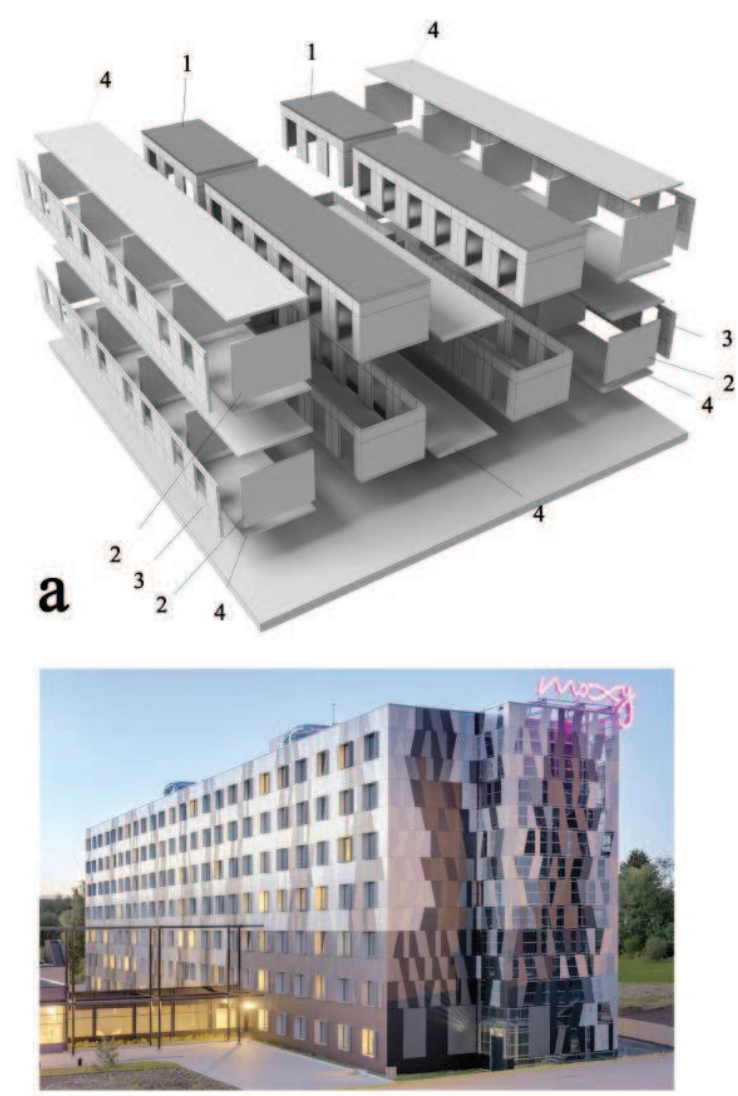

b
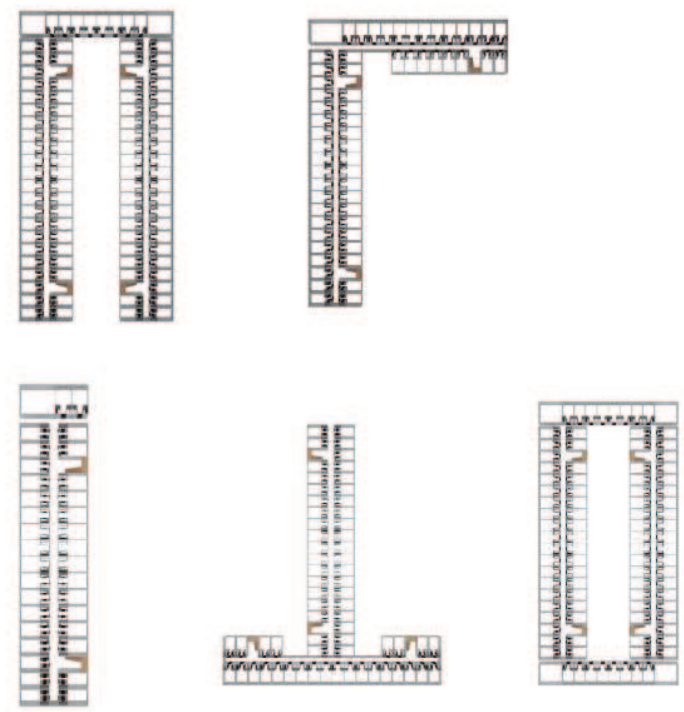

C

Fig. 9. Wooden modular design of the Moxy Hotel in Oslo $[16$ c. 4,5$]: a$ - Schematic diagram of the MOXI hotel; $b$-general view; $c-$ possible floor plans. 1 - Unit module; 2 and 3 - facade panels; 4 - Floor slabs (room and corridor) 


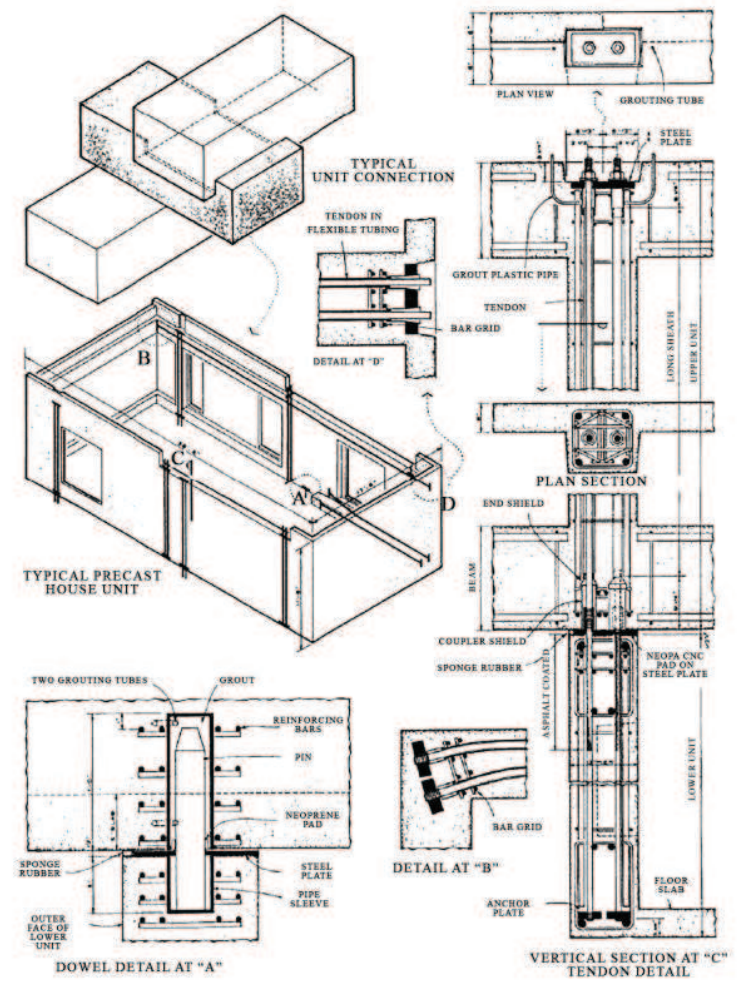

A

B

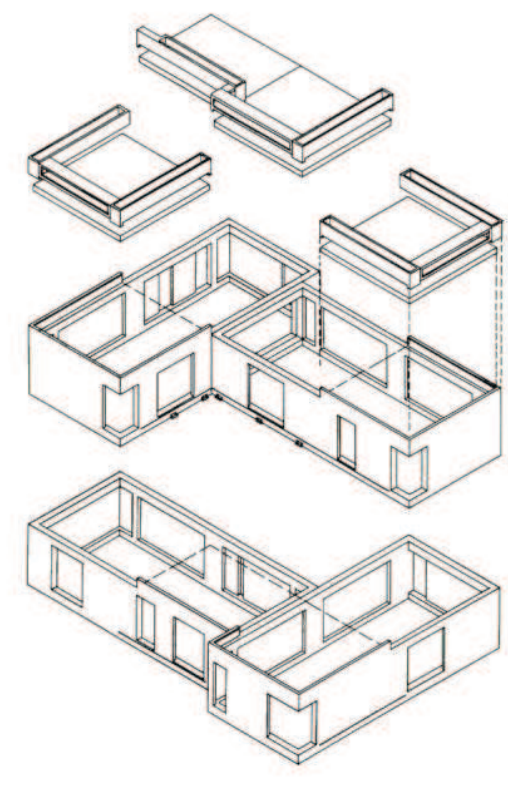

Fig.10. Habitat 67 in Montreal [15, p.63, 64]: $a$ - details of the strengthening and connection of the units; $b$ - units and methods for their combination

The open system includes two-dimensional elements (panels, columns, plates, beams, lintels, stairs), and the closed system includes three-dimensional (units) [13, p.10]. Such items are available in standard sizes and are affordable when purchased in large quantities. Practice shows that mini-systems of components or integrated elements are more widely used. It is also worth mentioning that reinforced concrete elements are more often combined with other construction materials. In this respect, prefabricated concrete foundation elements are used in combination with any other type of modular constructions due to their ease of application in dirty environments and in the presence of fragile ground structure. Bearing wall panels in multi-story buildings can take place as diaphragms and rigid cores, in the space between which service and circulation modules are located. In low-rise buildings, the most common option is a transverse structure with partitions between different zones [16, p.14].

Units are often used to create sites that require intensive maintenance (built-in kitchens, bathrooms and showers, laboratories), where there is a high degree of repeatability and the need for quick assembly on site. Bearing sanitary units are capable of perceiving the load not only from their own weight, but also from floor structures based on them [3, p.108].

Modular reinforced concrete units are ideal for the design of temporary residence buildings (hotels, hostels) in science parks, as well as laboratory and office buildings. Large reinforced concrete units are mainly designated for dealers and manufacturers, including: general offices (construction site trailers, construction trailers); educational portables; commercial, retail, restaurant and convenience stores; military and government; kiosks, guardhouses and communication shelters; health care; industrial and workforce housing [18, p.162].

\section{CONCLUSION}

The modular structuring of the architectural and planning solution of the innovative direction buildings accommodates the development and organization of various functional zones in the form of buildings and squares, as well as in the form of premises. If we are talking about territorial modular structuring, the following schemes are recommended: combined and 
specialized. When combined, various functional areas are included. This scheme is valid for the reconstruction of existing buildings and the IE design in the grid of densely built-up areas. A specialized scheme that should be used to IE design in undeveloped territories allows rational structuring of functional zones in individual groups. At the building level, modular grids of supporting structures and the use of large-spatial blocks are recommended. Modular container blocks can be used for office and laboratory buildings. Such blocks may be prefabricated or semi-prefabricated. Depending on the purpose of designing modular buildings (temporary, long-term), such blocks can be built from different materials (plastic, reinforced concrete, truss metal structures). Plastic blocks are used for temporary and mobile buildings due to their low weight and simple installation and dismantling process. Steel farm containers are spread over all types of buildings, but in innovative enterprises (industrial parks, innovation centers, factories, research centers) are more suitable for designing workshops, warehouses, offices and laboratories. They can be built in two ways: reconstruction of warehouse containers and the use of specially prepared elements. Metal frames take the main load in such blocks. Wooden modules can be used as separate elements (panels and beams) or as ready-made block units. The disadvantage of such modules is the limited number of floors. Reinforced concrete modules as well as wooden are used in the form of elements and large blocks. They can be used for a wide range of buildings. They are durable and not limited to number of floors. However, due to transportation difficulties and heavy weight, they are limited in size. In addition, the installation and dismantling process for them is more complicated than other types of modular designs. It should be noted that with the transition from two-dimensional elements (beams, columns, panels) to threedimensional (units), the degree of design flexibility decreases. On the other hand, the dimensions of vehicles determine the maximum dimensions of the modules. Thus, the application of one or another solution is individual for each project.

\section{Sources of illustrations:}

Fig. 2 - according to [1] in the author's interpretation;

Fig. 6 - [20];

Fig. $8-[11]$;

Fig. $9-[16]$;

Fig. $10-[15]$.

\section{REFERENCES}

1. Breybruk S., Goodman H. Gold B., 1990. Proektirovanije nauchno-issledovatelskyh centrov [The architectural design of scientific centers]. Moscow, Strojzdat, 200 (in Russian).

2. Yezhov V.I., 2006. Arhitektura obshestvennih zdanija i kompleksov [The architecture of public buildings and complexes]. Kyiv, Vistka, 299-340.

3. Yezhov V.I., Slepcov O.S., Guseva E.V., 1998. Arhitekturno-konstruktivnyje systemi grajdanskyh zdanij [Architectural and constructive systems of civil buildings]. Kyiv, ArtEk, 324 (in Russian).

4. Klyunya V.L., 2011. Innovacionnoe predprijatije: sushnost, soderjanije I otlichitel"nije priznaki [Innovative enterprise: essential, content and distinctive features], Minsk, Vesnik BDU, Ekonomika, Ser.3, No.1, 5 (in Russian).

5. Modulnije in inventarnije zdanija na osnove karkasa is LSTK [Modular and inventory buildings on the basis of a framework made of light steel thin-walled structures], 19. Available at: http://isi.sfu-kras.ru/sites/is.institute.sfukras.ru/files/Prezentaciya_innovacii_8.pdf (04.05.2019) (in Russian).

6. Rumyantsev A.A., 2006. Arhitekturnoe formirovanije nauchno-proijzvodstvennyh zdanij innovacionnogo napravlenija [Architectural formation of innovative process in science parks]. The dissertation, Candidate of Architecture, Ural State Agrarian University, Yekaterinburg, 157.

7. Saveliev, B.A. Beljavskij A.V., Bocharov U.P., Gogulan M.F., Karpis E.E., Levenshtejn A.A., Metan'ev D.A., Platonov U.P., Shhusev M.A., 1979. Nauchnije kompleksi v zarubejnih stranah [Scientific complexes in foreign countries]. Moscow, Nauka, 172 (in Russian).

8. Sysoeva O.I. 2005. Rekonstrukcija promyshlennyh ob'ektov [Reconstruction of industrial facilities] Minsk, BNTU, Reverse context, 136 (in Russian). 
9. Khrustalev D.A. 2011. Arhitekturnaija organizacija innovacijonnogo processa $\mathrm{v}$ tehnoparkovyh struktur [Architectural formation of scientific and industrial buildings with innovation direction] The thesis, Candidate of Architecture, Moscow, MArchi, 300.

10. Braun M., Thomas J., Payette T., Ronald S., Richard K., 2001. Research laboratories. John Wiley \& Sons, Inc. New York, Chichester, Weinheim, Brisbane, Singapore, Toronto, 289

11. Cantu R., 2011. Modular design: the advantages for contractors. Trend, Iss.17, Washington, 3.

12. Garrison J., Tweedie A., 2008. Modular Architecture Manual. Kullman Buildings Corporation and Garrison Architects, USA, 104.

13. Glass J., 2000. The future for precast concrete in low-rise housing. British Precast Concrete Federation, Leicestershire, UK, 62.

14. Hardo Braun Grömling Dieter, Birkhäuser, 2005. Research and Technology Buildings. Publishers for Architecture. Basel, Berlin \& Boston, 235.

15. Hurd M. K., 1994. Precast concrete homes for safety, strength and durability. PCI Journal, March-April, 17.

16. Kavaliauskas J., 2017. Modular element system in high-rise wooden buildings: challenges, advantages and perspective. 23-th Internationales Holzbau-Forum IHF, Germany, 5.

17. Permanent modular construction, 2011. annual report, Available at: http://www.modular.org/documents/document publication/2011permanent.pdf. $\quad$ (29.09.2019), Virginia, 15.

18. Smith R.E., 2010. Prefab architecture, a guide to modular design and construction. John Wiley \& Sons, Inc., Hoboken, New Jersey, 402.

19. Macdonald A.J.2001. Structure and architecture. Plant A Tree, second edition, Department of Architecture, University of Edinburgh, 152.

20. As-tu déjà oublié. Available at: http://astudejaoublie.blogspot.com (03.06.2017) (in French).

21. Jurij Sobko, Evgenija Novak, 2018. Organizacijni ta tehnologichni rishennja dlja sposobu pidnjattja velikorozmirnih pokrittiv vantazhopidjomnimi vstanovljujuchimi moduljami na tr'oh domkratah. Underwater Technologies, Vol.08, 80-82 (in Ukrainian).

\section{Применение модульной системы в проектировании инновационных зданий}

Каземи Лари Голамали

Аннотация. Рассматриваются приёмы модульного регулирования в проектировании инновационных предприятий с целью повышения эффективности эксплуатации, а также создания более рационального метода расширения и трансформации. Следовательно, причислены преимущества модульной архитектуры в снижении стоимости, труда и расходов строительных материалов по сравнению с традиционными методами. Рассказывается о том, как модульная архитектура способствует дальнейшие расширения зданий. На основе научных исследований определены два класса модульной системы для регулирования архитектурной структуры существующих и новых объектов инновационного характера: совмещённая и специализированная. Подобные системы реализуются в виде сетки, ячеистой структуры и сборных блоков, позволяющих комбинирование однородных и неоднородных функциональных зон. При этом определены наиболее приемлемые габариты модулей для основных видов помещений инновационных предприятий: офисных, лабораторных и производственных. Рекомендуется применение того или иного типа модульного решения, адаптирующегося под требования местности и функционального процесса для инновационных зданий различного назначения.

Представлены приёмы блочного модулирования для строительства временных, постоянных и мобильных зданий инновационных предприятий. Рассмотрены сборные модули, в число которых входят плоские материалы и пространственные блоки. Металлические, деревянные, пластмассовые и железобетонные развёртки и блоки для создания модульных систем являются предметами изучения в этой статье. Также названы некоторые компании, которые разработали типичные модульные здания из подобных строительных материалов. Проанализированы способы соединения и сбора данных модулей как на заводе, так и на строительной площадке. Показана связь между габаритами модульных конструкций и транспортных средств. Для каждого из выше упомянутых разделов приведены примеры из мирового опыта.

Ключевые слова: инновационное предприятие, технопарк, модульная система, универсальность, гибкость, функциональная зона, рабочая ячейка. 